\title{
М.П. КОЛПАЧЕВА - ВЫПУСКНИЦА ПЕРВОЙ ВОЛНЫ ИНЖЕНЕРОВ-ГИДРОЛОГОВ ВОРОНЕЖСКОГО ГОСУДАРСТВЕННОГО УНИВЕРСИТЕТА
}

\author{
В.А. Дмитриева \\ Воронежский государственный университет, Россия \\ Поступила в редакцию 2 сентября 2019 г.
}

\begin{abstract}
Аннотация: В статье доктор географических наук В. А. Дмитриева в 5 День памяти вспоминает о выпускнице географического факультета ВГУ, доценте, кандидате географических наук, коллеге Марии Павловне Колпачевой.
\end{abstract}

Ключевые слова: студент, ученый-гидролог, университет.

\section{M.P. Kolpacheva - a graduate of the first wave of hydrological engineers Voronezh State University}

\section{V.A. Dmitrieva}

Abstract: In the article, Doctor of Geographical Sciences V. A. Dmitrieva, on Memorial Day 5, recalls a graduate of the Faculty of Geography of Voronezh State University, associate professor, candidate of geographical sciences, colleague Maria Pavlovna Kolpacheva.

Key words: student, hydrologist, university.

Мария Павловна Колпачева со студенческих лет связала свою судьбу с Воронежским университетом. Родилась Мария Павловна 12 мая 1923 года в с. Бобяково Новоусманского района Воронежской области. Сегодня Бобяково располагается совсем неподалеку от городской черты областного центра города Воронеж. Там же успешно окончила среднюю школу и сразу по ее окончании в 1940 году поступила на 1 курс физико-математического факультета ВГУ.

На физико-математическом факультете в это время открылась новая кафедра, где изучалась физика русловых процессов. Руководил кафедрой геофизики, именно так она называлась, доктор технических наук, профессор Н. П. Чеботарев. Его имя было хорошо известно не только в сфере образования и науки, но и обширной производственной деятельности, предшествовавшей его приходу в Воронежский университет. Профессиональное образование Н. П. Чеботарев получил на инженерно-мелиоративном факультете Харьковского сельскохозяйственного института. После завершения учебы он работал на различных должностях, в том числе и руководящих, в водохозяйствен-

(ㄷ Дмитриева В.А., 2019 ных организациях Украины, организовывал гидрологические изыскания, проводил экспертизы проектов гидротехнических сооружений, разрабатывал проекты малых ГЭС на реках Северский Донец и Псел. Обладая широкой эрудицией, разносторонними интересами и знаниями, Н. П. Чеботарев успешно совмещал производственную деятельность с научной и учебной работой, проявив при этом недюжинный организаторский, педагогический и исследовательский талант. Руководство Воронежского университета пригласило Н.П. Чеботарева для организации нового образовательного и научного направления в подготовке молодых специалистов, а именно, инженерной гидрологии, закрепившейся впоследствии в вузе на долгие годы.

Система образования на факультете была такой, что вначале, на 2-х младших курсах, студенты постигали общие предметы, а специализация начиналась на старших курсах. Знакомство со спецификой подготовки специалистов проводили заведующие кафедрами и ведущие ученые. При распределении студентов физико-математического факультета по кафедрам для освоения и получения специализации яркие рассказы Н.П. Чебота- 
рева о профессии покоряли сердца студентов. К ним принадлежала и М. П. Колпачева.

Но обучение на факультете юной студентки длилось совсем недолго: 1940-1942 годы. Грянула Великая Отечественная война. Она стала рубежным событием и в истории советского государства, и личной истории каждого советского человека. Студенты массово записывались в ряды добровольцев и уходили на фронт. Остававшиеся в стенах родного университета студенты и преподаватели совмещали учебу с трудовой деятельностью вне аудиторий - заготовка дров, уход за ранеными в госпиталях, работа в детских домах, рытье противотанковых рвов и многие другие востребованные в особых условиях военного времени виды работ. «Опаленная войной юность» - это о Марии Павловне и о многих других ее сверстниках, чьи годы совершеннолетия и взросления пришлись на тяжелый период грозовых сороковых лет.

Фронт приближался к Воронежу. Оставаться в городе было опасно, поэтому руководство города и университета приняло решение прекратить занятия в университете и эвакуироваться из Воронежа. Часть университета была отправлена в Липецк, часть в Татарскую республику, г. Елабугу. М. П. Колпачева, завершив обучение на 2-м курсе физико-математического факультета, в 1942 году во время начала боев за Воронеж, выехала на железнодорожную станцию Перелешино Воронежской области, где стала работать учителем математики в местной школе. Учительствовала Мария Павловна недолго - уже в 1943 году она возвращается в Воронеж и продолжает учебу в родном университете.

После освобождения Воронежа университет трудно и медленно восстанавливался - не хватало преподавательских кадров, не было оборудования, разгромлена и развезена библиотека. Разруха, холод и голод военного лихолетья находились рядом. Но были молодость и огромное желание учиться. В 1946 году М. П. Колпачева успешно оканчивает университет по выбранной специальности. В первый послевоенный год выпускной курс кафедры геофизики составили всего 7 человек, из них 6 девушек. Среди выпускников - М.П. Колпачева, А.Г. Курдов (позже аспирант, ассистент, доцент, профессор, заведующий кафедрой гидрологии суши в течение 20 лет), М. И. Смирнова (несколько лет преподававшая гидрометрию на кафедре гидрологии суши географического факультета, затем инженер-гидролог-прогнозист в Воронежском гидрометеоцентре), Р. И. Курдова (старший лабо- рант кафедры гидрологии суши, а затем старший преподаватель кафедры гидравлики в Воронежском политехническом университете). Первый выпуск дипломированных инженеров-гидрологов составил основу кафедры гидрологии суши, открывшуюся на географическом факультете ВГУ в 1949-1950 учебном году и начавшую подготовку по специальности гидролог-географ.

В 1946 году М. П. Колпачева поступает в аспирантуру при кафедре геофизики физико-математического факультета. Ее научным руководителем был профессор Н. П. Чеботарев. Под его руководством на кафедре геофизики была создана уникальная гидрологическая лаборатория с самым совершенным на тот момент оборудованием, что позволяло аспирантам и студентам плодотворно заниматься экспериментальной научной деятельностью. Завершив обучение в аспирантуре в 1949 году, М.П. Колпачева уезжает на преподавательскую работу в Молотовский (ныне Пермский) государственный университет, где в должности ассистента кафедры физической географии работает в 1950 и 1951 годах. В 1951 году она возвращается в Воронеж, где была зачислена в штат кафедры гидрологи суши.

В послевоенные годы кафедра гидрологии жила яркой и насыщенной жизнью. На кафедре велась совместная научно-производственная деятельность преподавателей и студентов, выполнялись хоздоговорные работы с различными организациями. Интересным и крайне важным был договор, заключенный между Воронежским университетом и Управлением Юго-Восточной железной дороги в 1947 году. От сотрудников и студентов кафедры требовалось дать аргументированное заключение о воздействии стока половодья рек Тихая Сосна и Дон на насыпь железнодорожного полотна на участке железной дороги Лиски-Острогожск в годы исключительно высокой водности. От них требовалось определить расходы воды в реках очень редкой повторяемости, например, 1 раз в 100 лет, оценить на их основе размеры затопления и возможности размыва и обрушения железнодорожной насыпи. Были и другие масштабные проекты, в которых принимали участие преподаватели и студенты, например, проектирование в Воронежской области искусственных водоемов (прудов) для орошения и прочих нужд. Материалы научно-производственной деятельности использовались при написании курсовых и дипломных работ, кандидатских диссертаций. 
Важной вехой в жизни М. П. Колпачевой стала защита кандидатской диссертации и присуждение ученой степени кандидата географических наук в 1952 году. Спустя 3 года, М. П. Колпачева избирается на должность доцента кафедры гидрологии суши и в этой должности работает до ухода на пенсию в 1987 году.

Автору этих строк довелось быть студенткой Марии Павловны, а затем и коллегой. Она была строгим, принципиальным, требовательным, иногда бескомпромиссным и очень ответственным преподавателем. Мария Павловна вела сложную дисциплину - Динамика русловых потоков, преподавание которой требовало хорошей физико-математической подготовки. Этот курс был основным в ее педагогической нагрузке все годы работы на кафедре. Мария Павловна умела объяснить материал доходчиво и понятно, донести до слушателей очень сложные премудрости дисциплины, за что ее уважали студенты. Среди других дисциплин в учебной работе М. П. были Гидрология, Водно-балансовые исследования, Гидрофизика.

Одновременно с учебной работой Мария Павловна долгие годы руководила научной студенческой работой студентов и была бессменным руководителем научного студенческого кружка кафедры гидрологии суши. В нем успешно осваивали азы и получали навыки научных исследований, ставшие впоследствии кандидатами и докторами наук В. И. Бабкин, Ю. М. Михайлов, А. В. Васильев, С. Д. Дегтярев, В. К. Рязанцев, В. Н. Жердев и многие другие.

При этом и сама М.П. Колпачева вела активную научно-исследовательскую и публикационную деятельность. Областью научных интересов было изучение внутригодового распределения речного стока, а также изучение сезонного речного стока. Следует заметить, что сезонный сток и внут-

Дмитриева Вера Александровна

доктор географических наук, профессор кафедры природопользования факультета географии, геоэкологии и туризма Воронежского государственного университета, г. Воронеж, т. (473) 266-56-54, E-mail: verba47@list.ru ригодовое распределение стока остаются до сих пор недостаточно изученными в методическом отношении по сравнению с другими категориями речного стока (годовой, максимальный, минимальный). Она была автором многочисленных статей, а также соавтором ряда кафедральных монографий, среди которых «Карты стока рек и временных водотоков» (1975), «Расчеты стока рек и временных водотоков» (1979), «Картирование стока рек и временных водотоков» (1987) и других, вышедших на кафедре гидрологии суши под научным руководством профессора А. Г. Курдова.

М.П. Колпачева всегда была востребована как специалист. Она принимала активное участие в хоздоговорных и научно-исследовательских работах, посвященных изучению стока рек Центрального Черноземья, Башкирии, Челябинской области, где разрабатывалась методика определения основных гидрологических характеристик и расчета водных ресурсов в различные по водности годы, прогнозирование гидрологических событий, картографирование гидрологических параметров и оценка степени воздействия на водные источники антропогенной деятельности.

М.П. Колпачева успешно сочетала учебную методическую, научную деятельность с разноплановой общественной работой. Она много сил отдавала кураторской работе в студенческих группах, и многим-многим студентам помогала советом, мудрой подсказкой, напутствием. Принимала активное участие в факультетских мероприятиях. Поддерживала деловые отношения с выпускниками кафедры, учеными вузов и научных организаций.

Обладая хорошим физическим здоровьем, Мария Павловна трудилась с полной самоотдачей до последних лет пребывания на факультете, оставив после себя добрый человеческий след.

Dmitrieva Vera Alexandrovna

Doctor of Geographical Sciences, Professor of the Department of nature management, Faculty of Geography, Geoecology and Tourism, Voronezh State University, Voronezh, tel. (473) 266-56-54, E-mail: verba47@list.ru 